\title{
Direct labeling of nucleosides with 3-thiazolylcoumarin fluorescent dyes
}

\author{
Ia. B. Kuziv, I. Ya. Dubey \\ Institute of Molecular Biology and Genetics, NAS of Ukraine \\ 150, Akademika Zabolotnoho Str., Kyiv, Ukraine, 03143 \\ dubey@imbg.org.ua
}

\begin{abstract}
Aim. Preparation and study of nucleosides labeled with coumarin-based fluorophores without preliminary functionalization. Methods. Organic synthesis, absorption and fluorescence spectroscopy. Results. Direct labeling of 2'-deoxynucleosides with carboxy-modified 3-thiazolylcoumarins was performed. Coumarin conjugates were obtained by the reacting of active oxybenzotriazole esters of the dyes with nucleoside 5'-hydroxyl in the presence of a base, and with cytosine amino group. Their optical properties in methanol and phosphate buffer were studied. Conclusion. $\mathrm{N}$ - and $\mathrm{O}$-acylation of pyrimidine nucleosides with coumarin derivatives allowed to obtain conjugates with bright blue emission.
\end{abstract}

Ke y w o r d s: coumarins, nucleosides, fluorescent labeling, active esters

\section{Introduction}

Non-radioactive labeling of proteins, nucleic acids and other biomolecules allows their visualization and quantification to study the biological functions and dynamics. Applications of biomolecules carrying fluorescent reporter groups include research on their cellular transport, interactions with other molecules, bioimaging, medical diagnostics, etc. [1,2].

Fluorescently labeled nucleosides are also an important tool of biomedical research. They are commonly used as building blocks in the synthesis (both chemical and enzymatic) of fluorescent oligonucleotide probes [1, 3-5]. At the same time, the fluorescent nucleosides themselves can be used in the studies of nucleic acids, enzymes of nucleoside and nucleic acid biosynthesis, and in diagnostics [4-11]. However, their synthesis often requires functionalized nucleoside derivatives, since native nucleosides contain functional groups (sugar hydroxyls, exocyclic amino and keto groups) of relatively low nucleophilicity, the selective modification of which is quite difficult. Thus, the labeling is usually performed with nucleosides functionalized with aliphatic amino, thiol, aldehyde or other reactive groups [1-5].

C 2020 Ia. B. Kuziv et al.; Published by the Institute of Molecular Biology and Genetics, NAS of Ukraine on behalf of Biopolymers and Cell. This is an Open Access article distributed under the terms of the Creative Commons Attribution License (http://creativecommons.org/licenses/by/4.0/), which permits unrestricted reuse, distribution, and reproduction in any medium, provided the original work is properly cited 
Nucleosides were functionalized and then labeled at various positions: 5' - [12], 3' - [13] and 2'-hydroxyl [6], exocyclic $\mathrm{NH}_{2}[11,14]$, C- 5 of pyrimidine and C- 8 of purine bases $[5$, $7-10,15]$. Specific functionalization is a complicated synthetic task. We believe that in many cases $\mathrm{OH}$ functions of sugar moiety and amino groups of nucleoside bases can be used for direct labeling the reporter molecules.

Selective modification of nucleoside amino groups has attracted great attention in early period of the development of nucleoside chemistry. Application of numerous active compounds was investigated. The first attempt to selectively block cytidine, 2'-deoxycytidine and their 5'-phosphates with active esters was performed with 2-chloromethyl-4-nitrophenyl benzoate [16]. It was noted that adenosine and guanosine containing less basic amino groups were unable to react. Other authors employed pentaflurophenyl [17] and $p$-nitrophenyl [18] benzoates to block 2'-deoxycytidine. Katritzky et al. performed the acylation of cytidine, adenosine and deoxyadenosine by benzotriazoleactivated carboxyalkyl-modified fluorescent dyes [14]. We have previously studied active esters of amino acids as acylating agents for the nucleoside amino functions. Cytidine, adenosine and guanosine conjugates with amino acids were obtained from $\mathrm{O}$ - protected nucleosides [19]. Thus, active esters can be used for the acylation of exocyclic amino groups of nucleosides to prepare their conjugates.

Direct introduction of reporter groups at nucleoside hydroxyls is much more challenging, as these groups are not highly nucleophilic and thus require very active acylating agents. Most methods that are commonly used for the preparation of nucleoside esters are based on acyl halides or anhydrides. However, such reagents are not suitable for the attachment of labile reporting groups. Other esterification methods include transesterification of esters by alcohols under acidic or basic catalysis [20] and alkylation of carboxylic acids via Mitsunobu reaction [21].

Mild conditions of ester bond formation can be achieved by active ester approach. Direct $\mathrm{O}$-acylation with these reagents is complicated by relatively low reactivity of aliphatic $\mathrm{OH}-$ groups and a low acylation efficiency of active esters, although there are numerous reports on their use in this reaction [22-27]. Hydroxyl esterification with active esters is frequently used in multistep syntheses of various classes of compounds [28-33].

In most cases, active esters are obtained via the activation of carboxylic acids with phosphonium [23, 24, 26, 33] or uronium [24, 31, 32] coupling reagents or carbodiimides [22, $30]$ in the presence of such nucleophiles as 1-hydroxybenzotriazole (HOBT) [23-26, 29, $32,33]$, its aza-analog 1-hydroxy-7-azabenzotriazole (HOAT) [24, 29, 31], Oxyma reagent $[27,29,30]$. Alcohols can be also acylated by less reactive N-hydroxysuccinimide esters [28].

These esterification methods were used in the synthesis of amino acid esters [23, 27], depsipeptides [25, 28, 30], dendrimers [29], carbohydrate and glycoside derivatives [32, 33], and for the attachment of amino acids and nucleotides to polymer supports [24, 31,34]. However, we were unable to find any papers describing the direct attachment of reporter groups to hydroxyl functions of nucleosides.

Previously we have synthesized a series of carboxyl-modified UV-excitable 7-substituted 
3-hetarylcoumarins as biomolecular labeling reagents with bright blue fluorescence $[35,36]$. In the present work, we have attempted to obtain their nucleoside conjugates by active ester approach without nucleoside functionalization with aminoalkyl or other reactive group.

\section{Materials and Methods}

N,N'-dicyclohexylcarbodiimide (DCC) was obtained from Acros (Belgium), 2'-deoxynucleosides, 1-hydroxybenzotriazole (HOBT) and $\mathrm{N}, \mathrm{N}$-diisopropylethylamine (DIPEA) were purchased from Fluka (Germany), DMSO from Aldrich (USA). 3'-O-benzoylthymidine $\mathrm{dT}(\mathrm{Bz})$ was prepared by the standard procedure [37]. Coumarin derivatives 1, 2, 9, 10 were obtained according to [35].

Solvents for synthesis were obtained from Macrochim (Ukraine). DMF was dried by distillation over $\mathrm{CaO}, \mathrm{P}_{2} \mathrm{O}_{5}$ and stored over $3 \mathrm{~A}$ molecular sieves (Rathburn, UK). Dioxane was distilled over potassium hydroxide, DIPEA over sodium and stored over molecular sieves. Triethylamine was distilled over maleic anhydride and $\mathrm{CaO}$. HOBT was dried in vacuum with $\mathrm{P}_{2} \mathrm{O}_{5}$. Methanol for spectroscopy (Labskan, Ireland) was additionally purified by distillation over $\mathrm{KHSO}_{4}$ and $\mathrm{K}_{2} \mathrm{CO}_{3}$.

Phosphate buffers (PB) with certain $\mathrm{pH}$ were prepared by mixing solutions $(0.1 \mathrm{M})$ of $\mathrm{NaH}_{2} \mathrm{PO}_{4}, \mathrm{Na}_{2} \mathrm{HPO}_{4}$ and $\mathrm{Na}_{3} \mathrm{PO}_{4}$ in appropriate ratios. [The] $\mathrm{pH}$ values were measured by $\mathrm{pH}-\mathrm{meter}$ SevenEasy $\mathrm{pH}$ equipped with InLab 413 electrode (Mettler Toledo, Switzerland).

Column chromatography was performed on Silica gel 60 (0.04-0.063 mm, ROSS, Belgium) or Silica 60M (0.04-0.063 mm, MachereyNagel, Germany). Thin layer chromatography
(TLC) was carried out on Alugram Xtra Sil G/ $\mathrm{UV}_{254}$ plates (Macherey-Nagel) in systems $\mathrm{CH}_{2} \mathrm{Cl}_{2}-\mathrm{MeOH}$ 98:2 (A), $\mathrm{CH}_{2} \mathrm{Cl}_{2}-\mathrm{MeOH}$ 95:5 (B) and $\mathrm{CH}_{2} \mathrm{Cl}_{2}-\mathrm{MeOH}$ 9:1 (C). To visualize nucleosides, TLC plates were sprayed with a mixture $\mathrm{H}_{2} \mathrm{SO}_{4}-\mathrm{HOAc}$-anisaldehyde-EtOH 5:1:5:90 (v/v) and heated at $105-110^{\circ} \mathrm{C}$ (blue spots).

NMR spectra were obtained with Varian VXR-300 (300 MHz) and Varian Gemini-2000 $(400 \mathrm{MHz})$ instruments in DMSO-d 6 using tetramethylsilane as an internal standard; chemical shifts are given in ppm.

Chromato-mass-spectrometric analysis (LC-MS) was performed in the positive ion detection mode on Agilent 1100LC/MSD SL instrument (Agilent Technologies, USA) equipped with Zorbax-C18 Rapid Resolution HT Cartridge $(2.1 \times 30 \mathrm{~mm}, 1.8 \mu \mathrm{m})$ using a $0-100 \%$ gradient of acetonitrile in $0.1 \%$ formic acid.

Fluorescence spectra were recorded with Quanta Master 40 spectrofluorimeter (Photon Technology, Canada) in $1 \times 1 \mathrm{~cm}$ quartz cuvette. The slit width was $2.0 \mathrm{~nm}$ for excitation and emission, point time detection $0.1 \mathrm{~s}$, sample concentration was in the range $(0.5-1.5) \times 10^{-6} \mathrm{M}$. Emission was exited at absorption maximum and excitation was detected at emission maximum. The emission spectra of ionized forms of 7-hydroxycoumarin derivatives in methanol were recorded with excitation at $437 \mathrm{~nm}$. UV-Vis spectra were recorded on UV-2802 spectrophotometer (Unico, USA) in $1 \mathrm{~cm}$ quartz cuvette in methanol or $\mathrm{PB}$, with dyes and conjugates concentration in the range 4-35 $\mu \mathrm{M}$ (0.1-1.1 OD units). The stock solutions were prepared in methanol or DMSO. The fluorescence quantum yields of compounds $(\Phi)$ were determined by 
common procedure using Coumarin-1 ( $\mathrm{Em}_{\max }$ $445 \mathrm{~nm})$ and Coumarin-314 (Em $\left.{ }_{\max } 480 \mathrm{~nm}\right)$ as standards; their $\Phi$ values in EtOH are 0.50 and 0.58 , respectively [38].

The $\mathrm{pK}_{\mathrm{a}}$ values for 7-hydroxyxoumarin conjugates were obtained from HendersonHasselbach equation [39]:

$$
\log \left(\left(\mathrm{A}_{\mathrm{i}}-\mathrm{A}_{\mathrm{HA}}\right) /\left(\mathrm{A}_{\mathrm{A}^{-}}-\mathrm{A} i\right)\right)=\mathrm{pH}_{\mathrm{i}}-\mathrm{pK}_{\mathrm{a}}
$$

where $\mathrm{pH}_{\mathrm{i}}$ is $\mathrm{pH}$ of a given buffer, $\mathrm{A}_{\mathrm{i}}$ - absorbance of buffer with $\mathrm{pH}_{\mathrm{i}}, \mathrm{A}_{\mathrm{A}}{ }^{-}-$absorbance of the phenolate anion form of conjugate $(\mathrm{pH}$ above 9.5), $\mathrm{A}_{\mathrm{HA}}$ - absorbance of conjugate's acid forms ( $\mathrm{pH}$ below 5.0) at certain wavelength (in this case, $440 \mathrm{~nm}$ ). UV-Vis spectra were recorded at various $\mathrm{pH}$, then the plots of $\log \left(\left(\mathrm{A}_{\mathrm{i}}-\mathrm{A}_{\mathrm{pH} 4.7}\right) /\left(\mathrm{A}_{\mathrm{pH} 10}-\mathrm{A}_{\mathrm{i}}\right)\right)$ vs. $\mathrm{pH}$ were built and the $\mathrm{pK}_{\mathrm{a}}$ values were calculated.

General protocol for the synthesis of deoxycytidine conjugates

Reagent 1a, $\mathbf{1 b}, \mathbf{2 a}$ or $\mathbf{2 b}$ (dried in vacuum over $\mathrm{P}_{2} \mathrm{O}_{5}$ ) and anhydrous HOBT were dissolved in dry DMF (dye concentration $\sim 0.1 \mathrm{M}$ ), and DCC was added. After 4-hour activation, dry triethylamine and 2'-deoxycytidine hydrochloride were added, and the mixture was stirred at room temperature for a day. Molar ratio between $\mathrm{dC} \times \mathrm{HCl}, \mathrm{NEt}_{3}$, dye, $\mathrm{HOBT}$ and DCC was $1.0: 1.0: 1.2: 1.45: 1.38$. When the coupling was complete (TLC control), the mixture was evaporated and dried in vacuum over $\mathrm{P}_{2} \mathrm{O}_{5}$. The product was purified by silica gel column chromatography.

N - [ 1 - [ ( 2 S , 4 R , 5S ) - 4 - h y d r o x y - 5 (hydroxymethyl)tetrahydrofuran-2-yl]2-oxo-pyrimidin-4-yl]-2-[2-(7-hydroxy2-oxo-chromen-3-yl)thiazol-4-yl]acetamide (4a). Obtained from $1 \mathbf{a}(70 \mathrm{mg}, 0.23 \mathrm{mmol})$. Conjugate $4 a$ was eluted with $8 \% \mathrm{MeOH}$ in chloroform. Yellow powder (70 mg, 72\%). $\mathrm{R}_{\mathrm{f}}$ 0.33 (C). M.p. $224-226^{\circ} \mathrm{C} .{ }^{1} \mathrm{H}$ NMR: $\delta 11.17$ (1H, s, NH (Cyt)), 8.83 (1H, s, H-4), $8.36(1 \mathrm{H}$, $\mathrm{d}, \mathrm{J}=7.2 \mathrm{~Hz}, \mathrm{H}-6$ (Cyt)), 7.83 (1H, d, J = 8.4 $\mathrm{Hz}, \mathrm{H}-5), 7.58$ (1H, s, H-4 (thiazole)), 7.21 $(1 \mathrm{H}, \mathrm{d}, \mathrm{J}=7.2 \mathrm{~Hz}, \mathrm{H}-5$ (Cyt)), 6.87-6.79 (1H, m, H-6), 6.77 (1H, m, H-8), $6.11(1 \mathrm{H}, \mathrm{t}, \mathrm{J}=6.4$ $\mathrm{Hz}, \mathrm{H}-1$ '), 5.29 (1H, m, 3'-OH), 5.07 (1H, m, 5'-OH $), 4.22,3.85(2 \times 1 \mathrm{H}, 2 \mathrm{~m}, \mathrm{H}-3$ ', H-4'), 4.01 ( $\left.2 \mathrm{H}, \mathrm{s}, \mathrm{CH}_{2} \mathrm{COO}\right), 3.59$ (2H, m, H-5'), 2.3, $2.02(2 \times 1 \mathrm{H}, 2 \mathrm{~m}, \mathrm{H}-2$ ', 2" $)$. LC-MS: $m / z$ $512.9[\mathrm{M}+1]^{+}$.

N - [ 1 - [ ( 2 S , 4 R, 5 S ) - 4 - h y d r o x y - 5 (hydroxymethyl)tetrahydrofuran-2-yl]2-oxo-pyrimidin-4-yl]-4-[2-(7-hyd roxy2-oxo-chromen-3-yl)thiazol-4-yl]butanamide (4b). Obtained from $1 \mathbf{b}$ (76 mg, 0.23 $\mathrm{mmol})$. Labeled nucleoside $\mathbf{4 b}$ was eluted with $8 \% \mathrm{MeOH}$ in $\mathrm{CHCl}_{3}$. Yellow powder $(67 \mathrm{mg}$, $65 \%) . \mathrm{R}_{\mathrm{f}} 0.33$ (C). M.p. $169-171^{\circ} \mathrm{C} .{ }^{1} \mathrm{H}$ NMR: $\delta 10.89$ (1H, s, NH (Cyt)), 8.86 (1H, s, H-4), 8.32 (1H, d, J = 7.2 Hz, H-6 (Cyt)), 7.83 (1H, $\mathrm{d}, \mathrm{J}=8.4 \mathrm{~Hz}, \mathrm{H}-5), 7.42$ (1H, s, H-4 (thiazole)), 7.23 (1H, d, J = $7.6 \mathrm{~Hz}, \mathrm{H}-5$ (Cyt)), $6.85(1 \mathrm{H}, \mathrm{d}, \mathrm{J}=8.8 \mathrm{~Hz}, \mathrm{H}-6), 6.79(1 \mathrm{H}, \mathrm{s}$, $\mathrm{H}-8), 6.10$ (1H, t, J=6.2 Hz, H-1'), 5.28 (1H, s, broad, 3'-OH), 5.07 (1H, br.s, 5 ' $-\mathrm{OH}), 4.22$, 3.85 (2x1H, 2m, H-3', H-4'), 3.64-3.54 (2H, $\left.\mathrm{m}, \mathrm{H}-5^{\prime}\right), 2.79(2 \mathrm{H}, \mathrm{t}, \mathrm{J}=7.4 \mathrm{~Hz}$, $\left.\mathrm{CH}_{2} \mathrm{CH}_{2} \mathrm{CH}_{2} \mathrm{COO}\right), 2.45\left(\mathrm{CH}_{2} \mathrm{COO}+\mathrm{DMSO}\right.$,), 2.30-2.25(1H, m, H-2' or H-2"'), 2.02 (3H, m, H-2' or H-2', $\left.\mathrm{CH}_{2} \mathrm{CH}_{2} \mathrm{CH}_{2} \mathrm{COO}\right)$. LC-MS: $m / z$ $540.8[\mathrm{M}+1]^{+}$.

N - [ 1 - [ ( 2 R, 4 R, 5 S ) - 4 - h y d r ox y - 5 (hydroxymethyl)tetrahydrofuran-2-yl]2-oxo-pyrimidin-4-yl]-2-[2-(7-methoxy2-oxo-chromen-3-yl)thiazol-4-yl]acetamide 
(5a). Obtained from $2 \mathbf{2 a}(79 \mathrm{mg}, 0.25 \mathrm{mmol})$. Labeled nucleoside 5a was eluted with 4-6\% $\mathrm{MeOH}$ in chloroform. Crude material $(\sim 100$ $\mathrm{mg}$ ) was crystallized from dioxane-water mixture $(4: 3)$ to provide a yellow powder $(66 \mathrm{mg}$, $62 \%) . \mathrm{R}_{\mathrm{f}} 0.44$ (C). M.p. $189-191^{\circ} \mathrm{C} .{ }^{1} \mathrm{H}$ NMR: $\delta 11.17(1 \mathrm{H}, \mathrm{s}, \mathrm{NH}(\mathrm{Cyt})), 8.91(1 \mathrm{H}, \mathrm{s}, \mathrm{H}-4)$, $8.35(1 \mathrm{H}, \mathrm{d}, \mathrm{J}=7.5 \mathrm{~Hz}, \mathrm{H}-6(\mathrm{Cyt})), 7.95(1 \mathrm{H}$, $\mathrm{d}, \mathrm{J}=8.7 \mathrm{~Hz}, \mathrm{H}-5), 7.64(1 \mathrm{H}, \mathrm{s}, \mathrm{H}-4$ (thiazole)), $7.21(1 \mathrm{H}, \mathrm{d}, \mathrm{J}=7.5 \mathrm{~Hz}, \mathrm{H}-5$ (Cyt)), $7.14(1 \mathrm{H}, \mathrm{d}, \mathrm{J}=2.0 \mathrm{~Hz}, \mathrm{H}-8), 7.04(1 \mathrm{H}, \mathrm{dd}, \mathrm{J}$ $=2.0 \mathrm{~Hz}, 8.7 \mathrm{~Hz}, \mathrm{H}-6), 6.12(1 \mathrm{H}, \mathrm{t}, \mathrm{J}=6.7 \mathrm{~Hz}$, H-1'), $5.28\left(1 \mathrm{H}, \mathrm{d}, \mathrm{J}=3.9 \mathrm{~Hz}, 3^{\prime}-\mathrm{OH}\right), 5.05$ $\left(1 \mathrm{H}, \mathrm{t}, \mathrm{J}=5.0 \mathrm{~Hz}, 5^{\prime}-\mathrm{OH}\right), 4.21,3.86(2 \times 1 \mathrm{H}$, 2m, H-3', H-4'), 4.03 (2H, s, $\left.\mathrm{CH}_{2} \mathrm{COO}\right), 3.9$ $\left(3 \mathrm{H}, \mathrm{s}, \mathrm{OCH}_{3}\right), 3.59\left(2 \mathrm{H}, \mathrm{m}, \mathrm{H}-5^{\prime}\right), 2.3,2.02$ (2×1H, 2m, H-2', 2"). LC-MS: $m / z 527.2$ $[\mathrm{M}+1]^{+}$.

N- [ 1 - [ ( 2 R, 4 R, 5S ) - 4 - h yd roxy - 5 (hydroxymethyl)tetrahydrofuran-2-yl]2-oxo-pyrimidin-4-yl]-4-[2-(7-methoxy2-oxo-chromen-3-yl)thiazol-4-yl]butanamide (5b). Obtained from $\mathbf{2 b}$ (42 $\mathrm{mg}, 0.12$ $\mathrm{mmol}$ ). Product $5 \mathbf{b}$ was eluted with $5-6 \%$ $\mathrm{MeOH}$ in $\mathrm{CHCl}_{3}$, crystallized from aq. dioxane and dried in vacuum over $\mathrm{P}_{2} \mathrm{O}_{5}$. Yellow powder (26 mg, 50\%). $\mathrm{R}_{\mathrm{f}} 0.44$ (C). M.p. $145-147^{\circ} \mathrm{C}$. ${ }^{1} \mathrm{H}$ NMR: $\delta 10.86(1 \mathrm{H}, \mathrm{s}, \mathrm{NH}(\mathrm{Cyt})), 8.91(1 \mathrm{H}$, s, H-4), $8.32(1 \mathrm{H}, \mathrm{d}, \mathrm{J}=8.0 \mathrm{~Hz}, \mathrm{H}-6$ (Cyt)), $7.94(1 \mathrm{H}, \mathrm{d}, \mathrm{J}=8.8 \mathrm{~Hz}, \mathrm{H}-5), 7.44(1 \mathrm{H}, \mathrm{s}$, $\mathrm{H}-4($ thiazole $)), 7.23(1 \mathrm{H}, \mathrm{d}, \mathrm{J}=7.6 \mathrm{~Hz}, \mathrm{H}-5$ (Cyt)), $7.12(1 \mathrm{H}, \mathrm{d}, \mathrm{J}=2.2 \mathrm{~Hz}, \mathrm{H}-8), 7.03(1 \mathrm{H}$, $\mathrm{dd}, \mathrm{J}=2.4 \mathrm{~Hz}, \mathrm{~J}=8.4 \mathrm{~Hz}, \mathrm{H}-6), 6.1(1 \mathrm{H}, \mathrm{t}, \mathrm{J}=$ $6.4 \mathrm{~Hz}, \mathrm{H}-1$ '), $5.25\left(1 \mathrm{H}, \mathrm{d}, \mathrm{J}=4.4 \mathrm{~Hz}, 3^{\prime}-\mathrm{OH}\right)$, $5.03\left(1 \mathrm{H}, \mathrm{t}, \mathrm{J}=5.6 \mathrm{~Hz}, 5^{\prime}-\mathrm{OH}\right), 4.22,3.86$ $\left(2 \times 1 \mathrm{H}, 2 \mathrm{~m}, \mathrm{H}-3^{\prime}, \mathrm{H}-4\right.$ ') $3.9\left(3 \mathrm{H}, \mathrm{s}, \mathrm{OCH}_{3}\right)$, $3.59(2 \mathrm{H}, \mathrm{m}, \mathrm{H}-5$ '), $2.81(2 \mathrm{H}, \mathrm{t}, \mathrm{J}=7.2 \mathrm{~Hz}$, $\left.\mathrm{CH}_{2} \mathrm{CH}_{2} \mathrm{CH}_{2} \mathrm{COO}\right), 2.45-2.53(2 \mathrm{H}, \mathrm{m}$, $\mathrm{CH}_{2} \mathrm{COO}$ ), 2.29 (1H, m, H-2' or H-2"'), 2.30-
1.91 (3H, m, H-2' or H-2", $\left.\mathrm{CH}_{2} \mathrm{CH}_{2} \mathrm{CH}_{2} \mathrm{COO}\right)$. LC-MS: $m / z 555.2[\mathrm{M}+1]^{+}$.

General procedure for O-esterification of nucleosides

Reagent $2 \mathbf{a}$ or $\mathbf{2 b}$ (dried in vacuum over $\mathrm{P}_{2} \mathrm{O}_{5}$ ) and anhydrous HOBT were dissolved in dry DMF (dye concentration $\sim 0.1 \mathrm{M}$ ), and DCC was added. In $4 \mathrm{~h}$, DIPEA and 3'-O-benzoylthymidine were added, and the mixture was stirred at room temperature for 1.5 days. Molar ratio between $\mathrm{dT}(\mathrm{Bz})$, dye, HOBT, DCC and DIPEA was $1.0: 2.0: 2.4: 2.2: 2.0$. The mixture was diluted with dichloromethane, washed with aqueous citric acid, $\mathrm{NaHCO}_{3}$ and water, dried over sodium sulfate and evaporated. Crude material was chromatographed on silica gel column.

[(2S,3R,5R)-2-[[2-[2-(7-methoxy-2-oxochromen-3-yl)thiazol-4-yl] acetyl] oxymethyl]-5-(5-methyl-2,4-dioxo-pyrimidin-1-yl)tetrahydrofuran-3-yl] benzoate (6a). Obtained from 1a $(64 \mathrm{mg}, 0.2 \mathrm{mmol})$. Labeled nucleoside $6 \mathbf{a}$ was eluted with $1 \%$ methanol in chloroform. Yellow powder (42 $\mathrm{mg}, 65 \%) . \mathrm{R}_{\mathrm{f}} 0.43$ (A), 0.87 (B). M.p. 204$207^{\circ} \mathrm{C} .{ }^{1} \mathrm{H}$ NMR: $\delta 11.39(1 \mathrm{H}, \mathrm{s}, \mathrm{NH}(\mathrm{Thy}))$, $8.83(1 \mathrm{H}, \mathrm{s}, \mathrm{H}-4), 7.98(2 \mathrm{H}, \mathrm{d}, \mathrm{J}=7.8 \mathrm{~Hz}$, Ph-2,6), $7.87(1 \mathrm{H}, \mathrm{d}, \mathrm{J}=8.7 \mathrm{~Hz}, 5-\mathrm{H}), 7.7-7.48$ (5H, 2m, H-4 (thiazole), Ph-3,4,5, H-6 (Thy)), $7.12(1 \mathrm{H}, \mathrm{s}, \mathrm{H}-8), 7.02(1 \mathrm{H}, \mathrm{d}, \mathrm{J}=8.7 \mathrm{~Hz}$, H-6), $6.26(1 \mathrm{H}, \mathrm{t}, \mathrm{J}=7.2 \mathrm{~Hz}, \mathrm{H}-1$ ' $), 5.43(1 \mathrm{H}$, m, H-3'), 4.51-4.35 (3H, m, H-4', H-5'), 4.06, $3.98\left(2 \mathrm{H}, 2 \mathrm{~d}, \mathrm{~J}=16.8 \mathrm{~Hz}, \mathrm{CH}_{2} \mathrm{COO}\right), 3.90$ (3H, s, $\left.\mathrm{OCH}_{3}\right), 2.41$ (2H, m, H-2', H-2') 1.79 $\left(3 \mathrm{H}, \mathrm{s}, \mathrm{CH}_{3}\right.$ (Thy)). LC-MS: $m / z 646.3[\mathrm{M}+1]^{+}$. [(2R,3R,5S)-2-[4-[2-(7-methoxy-2-oxoc h r o m e n - 3 - y l) t h i a z o l - 4 - y l ] butanoyloxymethyl]-5-(5-methyl-2,4-dioxo- 
pyrimidin-1-yl)tetrahydrofuran-3-yl] benzoate (6b). Obtained from $\mathbf{1 b}(70 \mathrm{mg}, 0.20$ mmol). Product was isolated in a gradient of $\mathrm{MeOH}$ in $\mathrm{CHCl}_{3}(0-1 \%)$. Yellow powder (48 $\mathrm{mg}, 70 \%$ ). $\mathrm{R}_{\mathrm{f}} 0.43$ (A). M.p. $179-181^{\circ} \mathrm{C} .{ }^{1} \mathrm{H}$ NMR: $\delta 11.36(1 \mathrm{H}, \mathrm{s}, \mathrm{NH}(\mathrm{Thy})), 8.88(1 \mathrm{H}, \mathrm{s}$, $\mathrm{H}-4), 8.01(2 \mathrm{H}, \mathrm{d}, \mathrm{J}=7.2 \mathrm{~Hz}, \mathrm{Ph}-2,6), 7.92$ $(1 \mathrm{H}, \mathrm{d}, \mathrm{J}=8.8 \mathrm{~Hz}, 5-\mathrm{H}), 7.69(1 \mathrm{H}, \mathrm{m}, \mathrm{Ph}-4)$, 7.51-7.58 (3H, m, Ph-3,5, H-6 (Thy)), 7.42 $(1 \mathrm{H}, \mathrm{s}, \mathrm{H}-4$ (thiazole)), $7.11(1 \mathrm{H}, \mathrm{d}, \mathrm{J}=2.4 \mathrm{~Hz}$, 8-H), $7.03(1 \mathrm{H}, \mathrm{dd}, \mathrm{J}=2.4 \mathrm{~Hz}, 8.8 \mathrm{~Hz}, \mathrm{H}-6)$, $6.28(1 \mathrm{H}, \mathrm{t}, \mathrm{J}=6.8 \mathrm{~Hz}, \mathrm{H}-1$ ' $), 5.46(1 \mathrm{H}, \mathrm{m}$, H-3'), 4.37 (3H, m, H-4', H-5'), 3.91 (3H, s, $\left.\mathrm{OCH}_{3}\right), 2.82(2 \mathrm{H}, \quad \mathrm{t}, \mathrm{J}=7.6 \mathrm{~Hz}$, $\mathrm{CH}_{2} \mathrm{CH}_{2} \mathrm{CH}_{2} \mathrm{COO}$ ), 2.43-2.55 (m, $\mathrm{CH}_{2} \mathrm{CO}$, H-2', H-2'"), 2.01 (2H, quint, $\mathrm{J}=7.6 \mathrm{~Hz}$, $\mathrm{CH}_{2} \mathrm{CH}_{2} \mathrm{CH}_{2} \mathrm{COO}$ ), 1.77 (3H, s, $\mathrm{CH}_{3}$ (Thy)). LC-MS: $m / z 674.2[\mathrm{M}+1]^{+}$.

\section{Results and Discussion}

\section{$N$-acylation of nucleosides}

Our previous studies on $\mathrm{N}$-acylation of $\mathrm{O}$-protected nucleosides with active esters [have] indicated that HOBT derivatives were the most efficient reagents, whereas pentafluorophenyl esters were less active [19]. In the present work we have studied the acylation of unprotected deoxycytidine by HOBT esters of carboxy-coumarins 1-2 (1.2 eq.) in DMF at room temperature. Active esters were prepared using DCC as activating reagent (Scheme 1). They were found to be selective for exocyclic $\mathrm{NH}_{2}$ over less nucleophilic sugar hydroxyls, so the level of O-acylation was low. Smooth coupling reaction allowed obtaining the conjugates 4-5 in good yields $(65-72 \%$ for methoxycoumarin derivatives $\mathbf{4 a , b}, 50-62 \%$ for 7-hydroxy analogs 5a,b).
We have also tested the acylation of unprotected purine nucleosides by $\mathbf{2 b}$ under reported condition. In case of adenosine, a major product was formed, but the reaction was very slow (about $20 \%$ conversion in a week, by TLC). This is in agreement with the published data $[17,19]$. In attempted labeling of free guanosine the reaction was also slow and the mixture of products was formed containing O-acylated compounds. Some authors suggest that amino functions of purine nucleosides do not require protection in oligonucleotide synthesis due to their low reactivity [40]. We did not isolate labeled purine nucleosides because of their low yields.

\section{5 '-Hydroxyl acylation}

O-acylation is usually carried out under basic catalysis with tertiary amine, such as triethylamine, DIPEA, 4-dimethylaminopyridine, etc. As it was mentioned above, carboxyl activation can be performed by phosphonium or uronium coupling reagents to form acyl intermediates able to react with hydroxyl groups. This approach provides high acylation yields (90-100\%), but high cost of reagents limits their use. Activation by less expensive carbodiimides in the presence of nucleophilic additives like HOBT [22] is very popular, despite lower yields and slower acylation.

We have studied the interaction of HOBT esters of carboxyalkyl-coumarins with nucleoside hydroxyl. 3'-O-benzoylthymidine was used as a model nucleoside with a single $\mathrm{OH}$ group. Dyes were activated with DCC-HOBT system in DMF (Scheme 1). Then nucleoside and DIPEA base were added; 2-fold molar excess of the dye over nucleoside was used. 


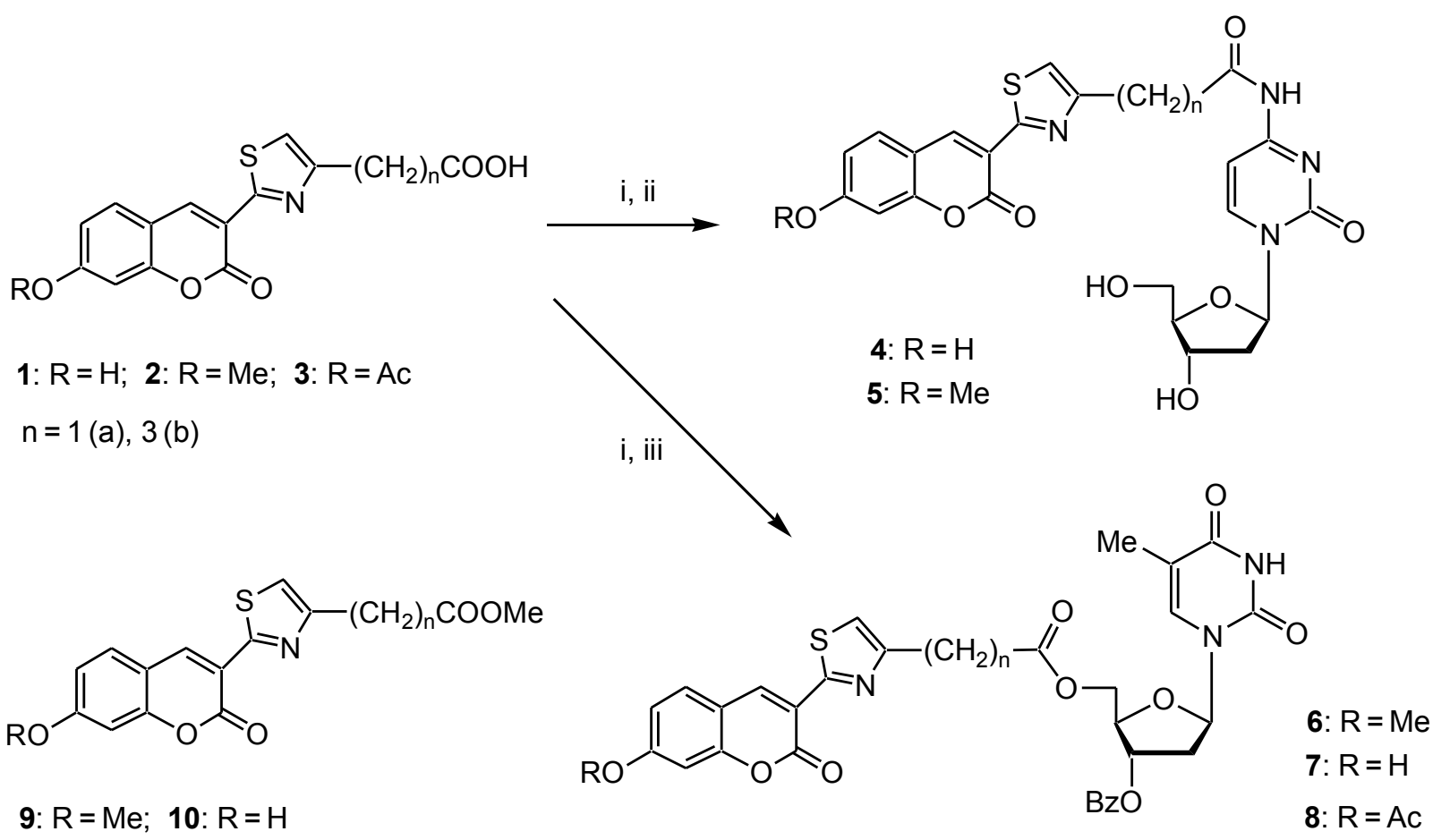

Scheme 1. Synthesis of N- and O-labeled nucleosides. (i). HOBT, DCC, DMF; (ii). dC $\times \mathrm{HCl}, \mathrm{NEt}_{3}$; (iii). 3'-O-benzoylthymidine, DIPEA. Dyes $\mathbf{9 , 1 0}$ were used as reference compounds in spectroscopic studies.

In addition to sugar hydroxyl, DIPEA can deprotonate also the phenolic $\mathrm{OH}$ of 7-hydroxycoumarins. As a result, 5'-O-labeling with coumarin reagents $\mathbf{1} \mathbf{a}, \mathbf{b}$ was not very efficient ( $40 \%$ conversion in 1.5 days and $\sim 60 \%$ in two weeks). The main reason of low yields could be the acylation of phenolic hydroxyl of compounds 1 and/or 7 by active ester upon DIPEA addition, with possible polycondensation. Compounds $\mathbf{7 a , b}$ were not isolated due to formation of complex reaction mixture and almost identical $R_{f}$ values of dyes and conjugates complicating their chromatographic separation.

Almost full conversion of nucleoside upon its reaction with active ester of $\mathbf{3} \mathbf{b}$ with acetylprotected phenolic $\mathrm{OH}$ was achieved in
1.5 days. However, partial loss of rather labile Ac group in the presence of such strong base as DIPEA was observed.

In contrast, coupling reactions between 7-methoxycoumarins $\mathbf{2 a , b}$ and $\mathrm{dT}(\mathrm{Bz})$ were smooth and efficient. Labeled nucleosides $\mathbf{6 a}$ and $\mathbf{6 b}$ were isolated in 65 and $70 \%$ yield, respectively.

All conjugates were characterized by NMR and LC-MS. Their purity was $>95 \%$.

In NMR spectrum of compound $\mathbf{6 a}$ the proton signals of methylene group of thiazole$\mathrm{CH}_{2}$-CO fragment appear as a doublet with a large coupling constant $(\mathrm{J}=16.8 \mathrm{~Hz})$. Thus $\mathrm{CH}_{2}$ protons in a short linker between dye and nucleoside are non-equivalent (AB system), perhaps due to restricted rotation around 
C4'-C5', ${ }^{\prime} 5^{\prime}-\mathrm{O}, \mathrm{CH}_{2}-\mathrm{COO}$ or thiazole- $\mathrm{CH}_{2}$ bonds. This may result from the interaction of three large hydrophobic fragments of the molecule (dye, thymine base and benzoyl group). Proton non-equivalency is not observed in the longer propylene linker of $\mathbf{6 b}$.

\section{Spectral properties of conjugates}

The spectral characteristics of compounds are presented in Table 1. UV-Vis spectra of conjugates are superpositions of dye and nucleoside absorption bands. The spectra of thymidine conjugates in methanol and phosphate buffer have two maxima in UV region, whereas those of 2'-deoxycytidine have three (Fig. 1, 2 ). In general, spectral properties of conjugates (shape, position and intensity of long-wavelength absorption and emission bands, quantum yields) are close to those of corresponding free dyes. The absorption (main band), excitation and emission spectra of coumarin fragments in compound $\mathbf{4 a - 6 a}, \mathbf{5 b}, \mathbf{6 b}$ well coincide with the spectra of free dyes 1-2 and reference dyes 9-10 with blocked $\mathrm{COOH}$

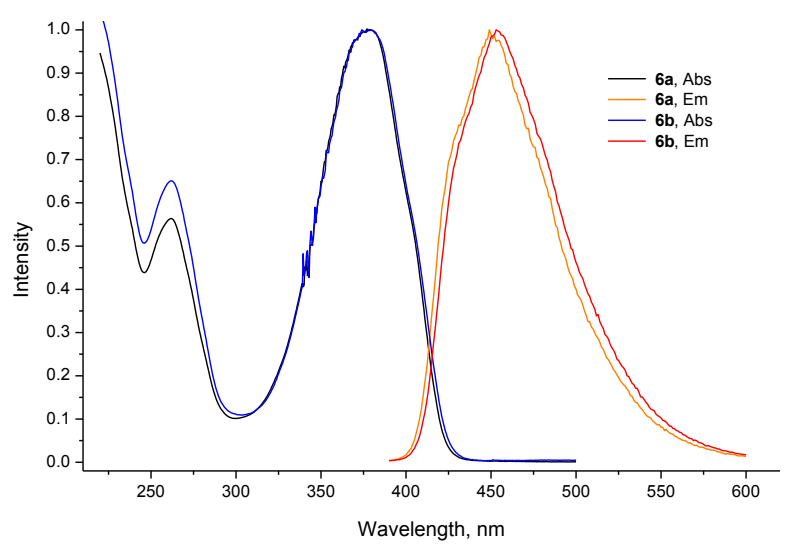

Fig. 1. Normalized absprption (Abs) and emission (Em) spectra of conjugates $6 \mathbf{a}$ and $\mathbf{6 b}$ in methanol $\left(\lambda_{\mathrm{ex}} 380 \mathrm{~nm}\right)$. group. However, in case of $\mathbf{4 b}$ there are spectral differences typical for intramolecular interactions (see below).

The excitation of 7-hydroxycoumarin conjugates $\mathbf{4 a , b}$ in $\mathrm{MeOH}$ at small long-wavelength shoulder above $430 \mathrm{~nm}$ results in the emission band shift from 455-458 to 483-484 nm (Fig. 2). This is due to the presence of some amount of ionized forms with different spectral properties. These forms become predominant in basic aqueous medium ( $\mathrm{pH}$ above 9-9.5); this is common for hydroxycoumarins [41].

Both UV-Vis and fluorescent spectra of hydroxycoumarins are $\mathrm{pH}$-dependent, in contrast to methoxy-analogs (Fig. 3-5). The shapes and positions of the main absorption bands of $\mathbf{4 a}$ and $\mathbf{1 a}$ are very close at $\mathrm{pH} 6.3$ and 10 . However, the main band of $\mathbf{4 b}$ is redshifted for $8 \mathrm{~nm}$ in comparison with $\mathbf{1 b}$ (Fig. 3) that can be due to the interaction of cytosine and dye fragments in $\mathbf{4 b}$.

In phosphate buffer ( $\mathrm{pH} 6.3$ and 10) excitation and emission spectra of conjugate $\mathbf{4 a}$ are

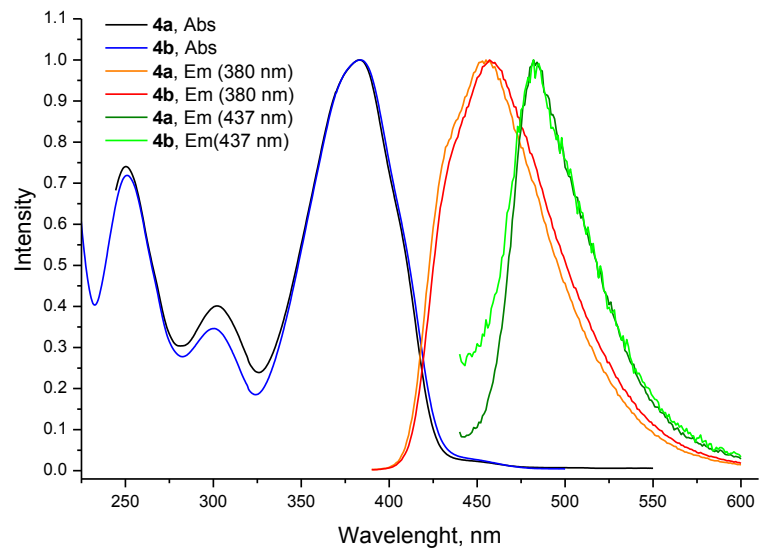

Fig. 2. Normalized absorption and emission spectra of $4 \mathbf{a}$ and 4b in $\mathrm{MeOH}$. Fluorescence was excited at 380 or $437 \mathrm{~nm}$. 


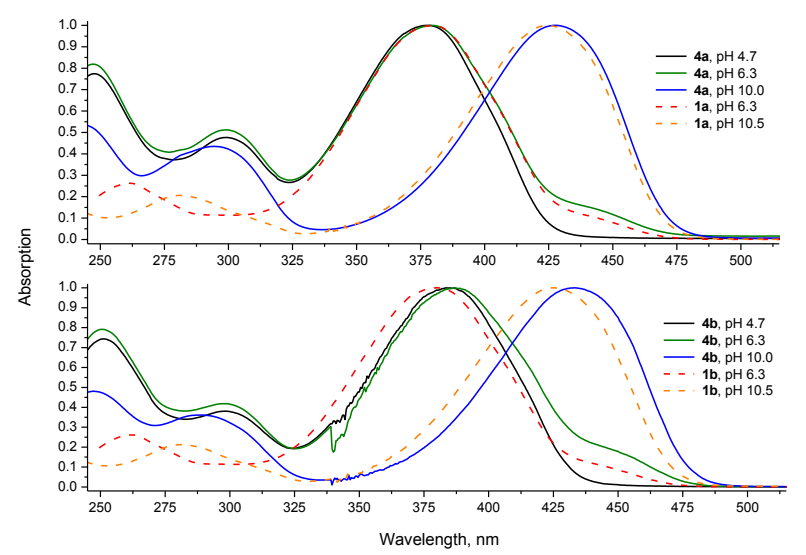

Fig. 3. Normalized UV-Vis spectra of hydroxycoumarin derivatives in phosphate buffer at various $\mathrm{pH}$.

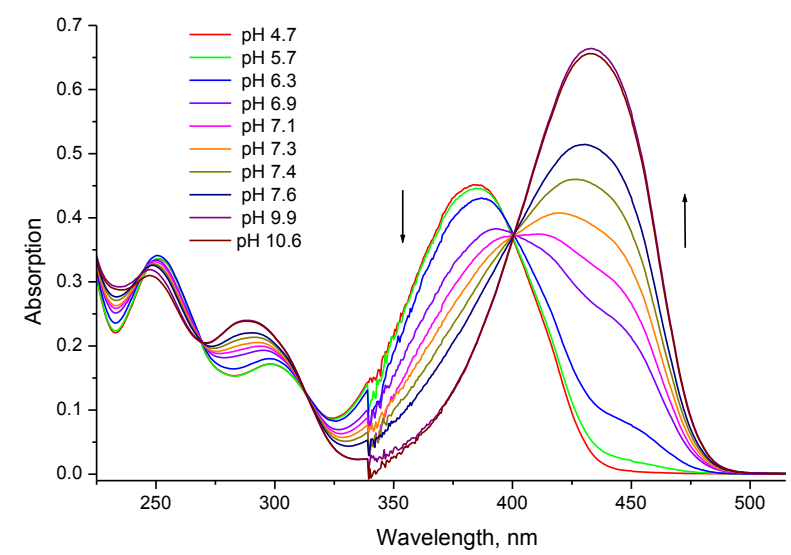

Fig. 5. $\mathrm{pH}$ dependence of UV-Vis spectrum of $\mathbf{4 b}$. Arrows indicate changes in absorption observed with $\mathrm{pH}$ increase.

close to corresponding spectra of 1a. Excitation spectrum of 4a coincides with its UV-Vis spectrum. Its quantum yield is rather close to that of $\mathbf{1 a}$ at $\mathrm{pH} 6.3$, but it is two times lower at basic $\mathrm{pH}$ (Table 1).

A strong decrease of the quantum yield of $\mathbf{4 b}$ in comparison with $\mathbf{1 b}$ is observed (about 2- and 6-fold at $\mathrm{pH} 6.3$ and 10, Table 1). The excitation spectrum of $\mathbf{4 b}$ at $\mathrm{pH} 10$ is blue-

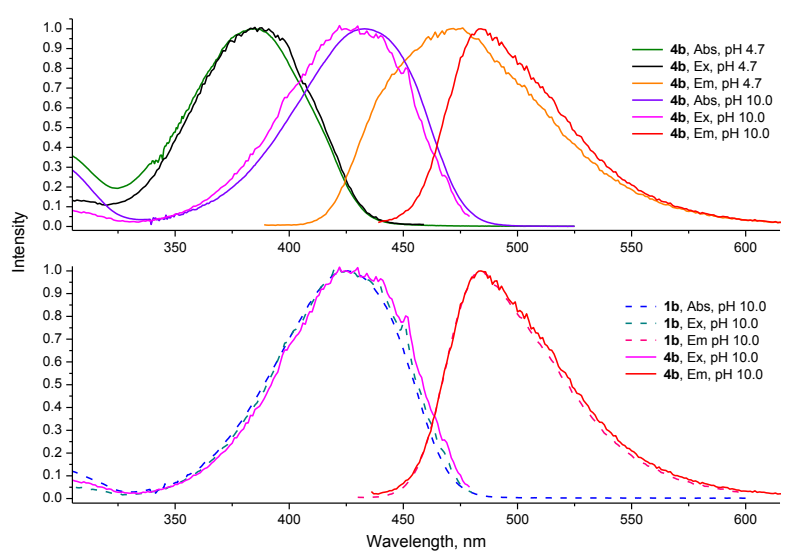

Fig. 4. Normalized UV-Vis, excitation and emission spectra of $\mathbf{1 b}$ and $\mathbf{4 b}$ in phosphate buffer at various $\mathrm{pH}$.

shifted for $\sim 8 \mathrm{~nm}$ relative to its absorption band (Fig. 4, top). This spectrum, however, is identical with the excitation spectrum of the dye $\mathbf{1 b}$, for which the excitation and absorption spectra are identical. The emission bands of the conjugate and $\mathbf{1 b}$ coincide (Fig. 5, bottom). These effects could be explained by the existence of $\mathbf{4 b}$ in two main conformational forms: open and "contact pair" between coumarin and cytosine moieties. In the open form $4 b$ behaves similarly to free dye or $\mathbf{4 a}$ containing shorter dye-nucleoside linker, whereas in the "contact pair" the fluorescence is quenched.

\section{$p K_{a}$ determination}

To determine the basicity of hydroxycoumarin conjugates we have used a HendersonHasselbach method [39]. In the titration experiments UV-Vis spectra were recorded in a broad range of $\mathrm{pH}$ (Fig. 5). From these data, the $\mathrm{pK}_{\mathrm{a}}$ values for $\mathbf{4 a}$ and $\mathbf{4 b}$ were obtained (7.3 and 7.2, respectively).

Thus, we have synthesized a series of dyenucleoside conjugates with intense blue fluo- 
Table 1. Optical properties of compounds.

\begin{tabular}{|c|c|c|c|c|c|c|c|}
\hline \multirow{2}{*}{ Compd } & \multirow{2}{*}{ Solvent } & \multicolumn{3}{|c|}{$\lambda_{\max }, \mathrm{nm}\left(\varepsilon, \times 10^{3} \mathrm{M}^{-1} \mathrm{~cm}^{-1}\right)$} & \multirow{2}{*}{$\mathrm{Ex}_{\max }$ (detected at), $\mathrm{nm}$} & \multirow{2}{*}{$\mathrm{Em}_{\max }$ (excited at), $\mathrm{nm}$} & \multirow{2}{*}{$\Phi$} \\
\hline & & band 1 & band 2 & band 3 & & & \\
\hline $1 \mathbf{a}$ & $\mathrm{MeOH}$ & $261(7.1)$ & - & $382(28)$ & $382(450)$ & $\begin{array}{l}457(380) \\
483(437)\end{array}$ & 0.84 \\
\hline $1 \mathrm{~b}$ & -"'- & $260(7.0)$ & - & $382(27)$ & $382(450)$ & $\begin{array}{l}457(380) \\
482(437) \\
\end{array}$ & 0.85 \\
\hline $2 a$ & -" & $257(7.4)$ & - & $378(29)$ & $381(450)$ & $453(380)$ & 0.71 \\
\hline $2 \mathbf{b}$ & -”- & $259(6.4)$ & - & $379(25)$ & $380(450)$ & $453(380)$ & 0.65 \\
\hline $3 \mathbf{b}$ & -"'- & $247(6.0)$ & $290(4.6)$ & $364(24)$ & $369(445)$ & $447(358)$ & 0.67 \\
\hline $4 a$ & -"- & $250(16)$ & $302(8.6)$ & $383(21)$ & $\begin{array}{l}382(452) \\
425(482) \\
\end{array}$ & $\begin{array}{l}455(380) \\
483(437) \\
\end{array}$ & 0.84 \\
\hline $4 \mathrm{~b}$ & -"- & $251(19)$ & $300(9.3)$ & $384(26)$ & $\begin{array}{l}382(452) \\
423(485)\end{array}$ & $\begin{array}{l}458(380) \\
484(437) \\
\end{array}$ & 0.83 \\
\hline $5 \mathbf{a}$ & -"- & $250(20)$ & $301(9.4)$ & $380(29)$ & $381(450)$ & $451(380)$ & 0.78 \\
\hline $5 \mathbf{b}$ & -"”- & $251(22)$ & $300(10)$ & $379(28)$ & $382(452)$ & $455(380)$ & 0.79 \\
\hline 6a & -"- & $262(17)$ & - & $380(31)$ & $381(450)$ & $452(380)$ & 0.73 \\
\hline $6 \mathbf{b}$ & -"- & $263(17)$ & - & $379(26)$ & $382(453)$ & $453(380)$ & 0.81 \\
\hline 9a & -"- & $257(7.6)$ & - & $378(30)$ & $380(450)$ & $449(380)$ & 0.81 \\
\hline $9 \mathrm{~b}$ & -"- & $259(7.1)$ & - & $378(27)$ & $380(450)$ & $453(380)$ & 0.80 \\
\hline $10 a$ & -"- & $260(7.0)$ & - & $382(28)$ & $382(450)$ & $\begin{array}{l}454(380) \\
482(437) \\
\end{array}$ & 0.76 \\
\hline $10 \mathrm{~b}$ & -"- & $261(7.7)$ & - & $383(29)$ & $382(450)$ & $\begin{array}{l}457(380) \\
482(437) \\
\end{array}$ & 0.85 \\
\hline $4 a$ & $\mathrm{~PB}, \mathrm{pH} 4.7$ & $249(15)$ & $300(9.4)$ & $379(20)$ & $380(480)$ & $476(378)$ & 0.64 \\
\hline $4 \mathrm{~b}$ & -" & $251(17)$ & $299(9.0)$ & $385(23)$ & $386(470)$ & $471(385)$ & 0.35 \\
\hline $1 \mathrm{a}$ & PB, pH 6.3 & $262(6.8)$ & - & $380(26)$ & $381(455)$ & $481(380)$ & 0.82 \\
\hline $1 \mathrm{~b}$ & -"- & $262(6.5)$ & - & $381(25)$ & $381(455)$ & $481(380)$ & 0.76 \\
\hline $4 a$ & -"- & $248(16)$ & $300(9.9)$ & $380(19)$ & $\begin{array}{l}380(455) \\
382(480) \\
\end{array}$ & $479(380)$ & 0.66 \\
\hline $4 \mathrm{~b}$ & -"'- & $251(18)$ & $299(9.5)$ & $387(23)$ & $388(455)$ & $473(388)$ & 0.32 \\
\hline $1 \mathrm{a}$ & $\mathrm{PB}, \mathrm{pH} 10$ & $281(7.8)$ & - & $424(38)$ & $425(485)$ & $483(425)$ & 0.71 \\
\hline $1 \mathrm{~b}$ & $-"$ & $282(7.4)$ & - & $425(35)$ & $425(485)$ & $484(425)$ & 0.69 \\
\hline $4 a$ & -"- & $245(16)$ & $296(13)$ & $429(29)$ & $425(483)$ & $483(426)$ & 0.35 \\
\hline $4 \mathrm{~b}$ & -"- & $248(17)$ & $299(13)$ & $433(35)$ & $425(483)$ & $\begin{array}{l}484(425) \\
484(433)\end{array}$ & 0.12 \\
\hline
\end{tabular}

rescence. Direct coupling of thiazolylcoumarin reagents to $\mathrm{NH}_{2}$-group of 2'-deoxycytidine and 5'-hydroxyl of 3'-benzoylthymidine was performed under mild conditions. Active esters react selectively with $\mathrm{dC}$ amino group, whereas the acylation of $\mathrm{OH}$ group requires the presence of a base.

\section{REFERENCES}

1. Gonçalves MST. Fluorescent labeling of biomolecules with organic probes. Chem. Rev. 2009; 109(1): 190-212.

2. Li C, Tebo AG, Gautier A. Fluorogenic labeling strategies for biological imaging. Int $J$ Mol Sci. 2017; 18: 1473. 
3. Wojczewski C, Stolze K, Engels JW. Fluorescent oligonucleotides - versatile tools as probes and primers for DNA and RNA analysis. Synlett 1999; 1999(10): 1667-78.

4. Sinkeldam RW, Greco NJ, Tor Y. Fluorescent analogs of biomolecular building blocks: design, properties, and applications. Chem Rev. 2010; 110(5): 2579-2619.

5. El-Sagheer AH, Brown T. Nucleic acid labeling, ligation, and modification. In: Chemoselective and Bioorthogonal Ligation Reactions. V. 2. (Ed. by Algar WR, Dawson PE, Medintz IL). Wiley, Weinheim, 2017. - p. 335-62.

6. Emmrich T, El-Tayeb A, Taha H, Seifert R, Müller CE, $\operatorname{Link} A$. Synthesis of a hydrolytically stable, fluorescentlabeled ATP analog as a tool for probing adenylyl cyclases. Bioorg Med Chem. Lett 2010; 20(1): 232-5.

7. Shinohara Y, Matsumoto K, Kugenuma K, Morii T, Saito Y, Saito I. Design of environmentally sensitive fluorescent 2'-deoxyguanosine containing arylethynyl moieties: distinction of thymine base by basediscriminating fluorescent (BDF) probe. Bioorg Med Chem Lett. 2010; 20(9): 2817-20.

8. Wilhelmsson LM. Fluorescent nucleic acid base analogues. $Q$ Rev Biophys. 2010; 43(2): 159-83.

9. Matsumoto K, Takahashi N, Suzuki A, Morii T, Saito Y, Saito I. Design and synthesis of highly solvatochromic fluorescent 2'-deoxyguanosine and 2'-deoxyadenosine analogs. Bioorg Med Chem Lett. 2011; 21(4): 1275-8.

10. Suzuki A, Takahashi N, Okada Y, Saito I, Nemoto N, Saito $Y$. Naphthalene-based environmentally sensitive fluorescent 8-substituted 2'-deoxyadenosines: application to DNA detection. Bioorg Med Chem Lett. 2013; 23(3): 886-92.

11. Goodwin KJ, Gangl E, Sarkar U, Pop-Damkov P, Jones N, Borodovsky A, Woessner R, Fretland AJ. Development of a quantification method for adenosine in tumors by LC-MS/MS with dansyl chloride derivatization. Anal Biochem. 2019; 568: 78-88.

12. De Schutter C, Roy V, Favetta P, Pavageau C, Maisonneuve S, Bogliotti N, Xie J, Agrofoglio LA. Synthesis and characterization of various 5 '-dye-labeled ribonucleosides. Org Biomol Chem. 2018; 16(35): 6552-63.

13. Prykota TI, Pfleiderer $W$. Nucleotides part LXXX: Synthesis of 3'-O fluorescence labeled thymidine derivatives and their 5'-o-triphosphates. Nucleosides Nucleotides Nucleic Acids 2011; 30(7-8): 544-51.
14. Katritzky AR, Ozcan S, Todadze E. Labeling of nucleosides with fluorescent 6-chloro-2,3-napthalimide. Bioorg Med Chem Lett. 2010; 20(17): 5326-8.

15. Shaughnessy KH. Palladium-catalyzed modification of unprotected nucleosides, nucleotides, and oligonucleotides. Molecules 2015; 20: 9419-54

16. Hata T, Kurihara T. The $\mathrm{N}^{4}$-benzoylation of deoxycytidilic and cytidylic acids by means of 2-chloromethyl-4-nitrophenyl benzoate. Chem Lett. 1973; 2(8): 859-62.

17. Igolen J, Morin C. Rapid syntheses of protected 2'-deoxycytidine derivatives. J Org Chem. 1980; 45(23): 4802-4.

18. Steinfeld AS, Naider F, Becker JM. A simple method for selective acylation of cytidines and cytosines under mild reaction conditions. $J$ Chem Res $(M)$. 1979: 1437-50.

19. Yarmoluk SM, Kostenko AM, Kryvorotenko DV, Dubey IYa. Nucleoside N-acylation with active derivatives of amino acids. Biopolym Cell 1996; 12(5): 50-5.

20. Otera J, Nishikido J. Esterification: Methods, Reactions, and Applications. $2^{\text {nd }} E d$. Wiley, Weinheim, 2010. - $386 \mathrm{p}$.

21. But TYS, Toy PH. The Mitsunobu reaction: origin, mechanism, improvements, and applications. Chem Asian J. 2007; 2(11): 1340-55.

22. Holmberg $K$, Hansen $B$. Ester synthesis with dicyclohexylcarbodiimide improved by acid catalysts. Acta Chem Scand B 1979; 33: 410-2.

23. Kim MH, Patel $D V$. "BOP" as a reagent for mild and efficient preparation of esters. Tetrahedron Lett. 1994; 35(31): 5603-6.

24. Pon RT, Yu S, Sanghvi YS. Rapid esterification of nueleosides to solid-phase supports for oligonucleotide synthesis using uronium and phosphonium coupling reagents. Bioconjug Chem. 1999; 10(6): 1051-7.

25. Klausner YS, Chorev M. Synthesis of depsipeptides by catalysis of active esters with 1-hydroxybenzotriazole. Chem Commun. 1975; (24): 973-4.

26. Coste J, Campagne J-M. A propos de l'estérification des acides carboxyliques par le BOP ou le PyBOP. Tetrahedron Lett. 1995; 36(24): 4253-6.

27. Subirós-Funosas R, Prohens R, Barbas R, El-Faham A, Albericio F. Oxyma: An efficient additive for peptide synthesis to replace the benzotriazole- 
based HOBt and HOAt with a lower risk of explosion. Chem Eur J. 2009; 15(37): 9394-403.

28. Stawikowski M, Cudic P. Depsipeptide synthesis. Methods Mol Biol. 2007; 386: 321-39.

29. Twibanire $J d A K$, Grindley TB. Polyester dendrimers: smart carriers for drug delivery. Polymers (Basel). 2014; 6(1): 179-213.

30. Wang Y, Aleiwi BA, Wang Q, Kurosu M. Selective esterifications of primary alcohols in a water-containing solvent. Org Lett. 2012; 14(18): 4910-3.

31. Bergmann F, Bannwarth W, Tam S. Solid phase synthesis of directly linked PNA-DNA-hybrids. Tetrahedron Lett. 1995; 36(38): 6823-6.

32. Twibanire JDAK, Omran RP, Grindley TB. Facile synthesis of a library of lyme disease glycolipid antigens. Org Lett. 2012; 14(15): 3909-11.

33. Chapleur Y, Castro B, Toubiana R. "Le BOP" reagent and imidazole for selective $\mathrm{O}$-acylation of trehalose. J Chem Soc Perkin Trans 1. 1980: 1940-3.

34. Dubey LV, Dubey IYa. Onium salts as coupling reagents in the preparation of silica polymer supports for oligonucleotide synthesis. Ukr Bioorg Acta. 2004; 1(1-2): 23-8.

35. Kuziv IaB, Ishchenko VV, Khilya VP, Dubey IYa. Synthesis of reagents based on 7-substituted 3-thiazolylcoumarins for covalent labeling of oligonucleotides. Ukr Bioorg Acta. 2008; 6(1): 3-12.

36. Kuziv IaB, Ishchenko VV, Khilya VP, Dubey IYa. Synthesis of carboxyalkyl derivatives of 3-furylcoumarins for the fluorescent labeling of biomolecules. Ukr Bioorg Acta. 2009; 7(2): 47-54.

37. Gait MJ (Ed.). Oligonucleotide synthesis: a practical approach. IRL Press, Oxford, 1984. $-218 \mathrm{p}$.

38. Reynolds GA, Drexhage KH. New coumarin dyes with rigidized structure for flash amp-pumped dye lasers. Opt. Commun. 1975; 13(3): 222-5.

39. Salgado LEV, Vargas-Hernández C. Spectrophotometric determination of the $\mathrm{pK}_{\mathrm{a}}$, isosbestic point and equation of absorbance vs $\mathrm{pH}$ for a universal $\mathrm{pH}$ indicator. Am J Anal Chem. 2014; 05(17): 1290-301.

40. Gryaznov SM, Letsinger RL. Synthesis of oligonucleotides via monomers with unprotected bases. J Am Chem Soc. 1991; 113(15): 5876-7.

41. Fink $D W$, Koehler WR. pH effects on fluorescence of umbelliferone. Anal Chem. 1970; 42(9): 990-3.
Пряме мічення нуклеозидів 3-тіазолілкумариновими флуоресцентними барвниками

Я.Б. Кузів, І.Я. Дубей

Мета. Отримання й дослідження нуклеозидів, мічених флуорофорами на основі кумарину без попередньої функціоналізації. Методи. Органічний синтез, адсорбційна та флуоресцентна спектроскопія. Результати. Проведене пряме мічення 2'-дезоксинуклеозидів карбокси-модифікованими тіазолілкумаринами. Кон'югати отримано реакцією гідроксибензотріазольних активованих естерів барвників з 5'-гідроксилом нуклеозиду в присутності основи або з аміногрупою цитозину. Досліджено їхні оптичні властивості в метанолі й фосфатному буфері. Висновки. N- та О-ацилювання піримідинових нуклеозидів похідними кумаринів дозволило отримати кон'югати з яскравою блакитною емісією.

К л ю ч о в i с л о в а: кумарини, нуклеозиди, флуоресцентне мічення, активовані естери

\section{Прямое мечение нуклеозидов}

3-тиазолилкумариновыми флуоресцентными красителями

Я.Б. Кузив, И.Я. Дубей

Цель. Получение и исследование нуклеозидов, меченых флуорофорами на основе кумарина без предварительной функционализации. Методы. Органический синтез, адсорбционная и флуоресцентная спектроскопия. Результаты. Проведено прямое мечение 2'-дезоксинуклеозидов карбокси-модифицированными тиазолилкумаринами. Конъюгаты получали реакцией оксибензотриазольных активированных эфиров красителей с 5'-гидроксилом нуклеозида в присутствии основания или с аминогруппой цитозина. Изучены их оптические свойства в метаноле и фосфатном буфере. Выводы. N- и О-ацилирование пиримидиновых нуклеозидов производными кумаринов позволило получить конъюгаты с яркой голубой эмиссией.

К л юч е в ы е с л о в а: кумарины, нуклеозиды, флуоресцентное мечение, активированные эфиры

Received 30.11.2019 